\title{
Environmental Health Evaluation for Jatinegara Apartment from the Perception of Kampung Pulo Displaced People
}

\author{
Deffi Ayu Puspito Sari ${ }^{1}$, Sandra Madonna ${ }^{1}$, Amalia Fitriani ${ }^{1}$ \\ ${ }^{1}$ Environmental Engineering, Universitas Bakrie, Jakarta, Indonesia \\ *Corresponding authorE-mail: deffi.sari@bakrie.ac.id
}

\begin{abstract}
Limited land availability and population growth resulted in the emergence of illegal housing and slums in Jakarta. Kampung Pulo area in East Jakarta is one of the regions occupied by the illegal structures and slums. To overcome the problem, the Government of DKI Jakarta built a simple rental apartment (Rusunawa) used for relocation of Kampung Pulo community. The aims of this research are to study the socio-economic condition of Rusunawa residents, the environmental health of Rusunawa Jatinegara compared to Kampung Pulo, and to know the influence of socio-economic status to the opinion of displaced people. Using descriptive method, scoring, analysis correlation and multiple regression (SPSS 16.0). The results show that majority of the education level of residents in Rusunawa Jatinegara is dominantly junior and senior high school, whereas the majority of their income is high. The parameter according to the public perception which is far better in Rusunawa compared within Kampung Pulo that is flood and animal transmitting diseases such as rats and flies. Partially the level of education affects the public perception while the income level does not change the public perception of the comparison between the environmental health in Rusunawa Jatinegara and the environmental health in Kampung Pulo. Simultaneously the level of the education and the income has positive impact to the public perception on the comparison of the environmental health in Rusunawa Jatinegara and the environmental health in kampong Pulo. Interestingly, apart from better environment health standar by Ministry of Health, according to the society's perception, 5 out of 20 parameters of the environmental health in Rusunawa is worse when it is compared to Kampung Pulo, the settings are water quality, rooms layout, lighting, sleeping area, and house building area.
\end{abstract}

Keywords: Kampung Pulo, Rusunawa Jatinegara, Relocation, Environmental Health, Socio-economic Condition, and Community Perception.

\section{Introduction}

Indonesia is the fourth country with largest population in the world after China, India and United States. According to population census in 2010 by Central Statistic Bureau, Indonesia's population has reached to more than 237 million people with 1.49 percent population growth per year [1]. Java island which cover only 6.8 percent of land area is the home for $57.5 \%$ population. Jakarta as capital city of Indonesia also in Java island. By 2015, 60\% of the population in Indonesia is located in the city, and about 10,177,924 people live in Jakarta with a population density of $15,366.87$ inhabitants per $\mathrm{km} \mathrm{[2].}$ This lead to the uncontrolled urbanization in Jakarta, the urbanization caused by the uneven development [3]. As the sign of development and growth, urbanization involves land converstion to meet the needs of society as well as infrastructure public goods and public facilities [4].

Limited land availability and the population growth resulted in the emergence of illegal buildings and slums in Jakarta. This slums area, high population density, squatters in river banks are vulnerable group and expose to increasing disaster risk lead to disaster such as flood disaster, epidemic, and fire [5]. Kampung Pulo area in East Jakarta is one of the regions targeted by the illegal buildings and slums [6]. This is because the area of Kampung Pulo has a strategic location with one of the economic centers of Jakarta, namely Jatinegara Market.

Kampung Pulo located on the banks of Ciliwung River and it is a lowland area causing the frequent floods, the floods can lead to the economic losses and impact on the public health such as skin deseases, itching, and diarrhea. Flood also causing infrastructure damage [7], eventhough flood is natural disaster, the magnitude of loss can increase do to lack of environmental concern, human intervention and bad management practices [8], [9]. Another problem which can be caused is the environmental health and the health problem in the community because Kampung Pulo area is not equipped with the provision of clean water, drainage, and waste transport facilities to the garbage dump.

To overcome the existing problems in Kampung Pulo area and with the limited availability of land in Jakarta, the Government of DKI Jakarta built a simple rental apartment (Rusunawa) located at Jatinegara barat Street No. 142, Jatinegara, East Jakarta which is used for relocation of Kampung Pulo Community. The definition os simple rental apartment (Rusunawa) based on PERMEN No. 14/2007 on Management of Simple Renting Apartment is a multi-storey building built in an environment which is divided into many structured sections and each unit used separately, lease tenancy status and made using the State Budget or Regional Revenue and Expenditure Budget with its primary function as a residence [10].

The location of Rusunawa Jatinegara is not far from Kampung Pulo, its only 1 kilometer. Jatinegara Rusunawa consists of two towers, each tower consists of 16 floors with the number of units in Rusunawa Jatinegara reach 518 units, the number of units in tower $\mathrm{A}$ is 266 units, and the number of units in tower B is 252 units. The number of household head (KK) which is relocated to Rusunawa Jatinegara as much as $631 \mathrm{KK}$ with the population reaches 2,180 people.

The purpose of Kampung Pulo community relocation is to improve the environmental health in settlements and to return the function of Kampung Pulo area as the river basin. The scope of the ecological health in housing such as the apartment is significant to be studied because it can affect the physiology and the psychology condition of the inhabitants. The example of physiological needs includes lighting, ventilation, noise, sufficient space, and so on. While the need for the psychological needs such as residential environment 
with the same economic level, a condition which is safe and comfortable for residents, adequate privacy and others.

There are three parameters to determine the condition of good house according to Decree of the Minister of Health Number 829/Menkes/SK/VII/1999 about the Housing Health Requirement which are: the component of house group, sanitation, and behavior of the resident. The house group components include ventilation, lighting, walls, and the disposal of kitchen fumes. The components of sanitation facilities include the clean water facilities, stool disposal, waste water disposal, and water bins. The components of the occupant behavior involve cleaning the house, throwing the garbage in its place, opening the window of the house and others [11].

Rusunawa Jatinegara was built in late 2013 and started to be used in 2015. In 2 years the people who have relocated have been able to feel the difference about the environmental health at home and sanitation between living in Rusunawa and Kampung Pulo. Therefore, this study was conducted to evaluate the environmental health in Rusunawa Jatinegara viewed from the perception of the people who moved from Kampung Pulo. The environmental health factors in a housing to be researched is based on Decree of the Minister of Health No. 829/Menkes/SK/VII/1999 about Housing Health Requirements covering housing and sanitation groups.

\section{Purpose of Study}

The purpose of this study is to study the socio-economic conditions of displaced people who moved to Rusunawa Jatinegara. To find out the comparison of the environmental health in Rusunawa Jatinegara with the environmental health in Kampung Pulo according to the social perception. To determine the effect of socio-economic conditions on the comparison of the environmental health perception in Rusunawa Jatinegara with the environmental health in Kampung Pulo.

\section{Research Methodology}

Data collection was done in two ways: the interview with questionnaires and the observations. The preparation of the questionnaires conducted to determine the parameters of the environmental health measurements in Rusunawa Jatinegara compared with the environmental health in Kampung Pulo. The scoring includes in three alternative answers; better, the same and worse. Each explanation is given a score; a score of 3 is better, a score of 2 is the same, and a score of 1 is worse. The length of class interval is calculated as follows:

Interval $=$ maximum score - minimum score

$$
\begin{aligned}
& =3-1 \\
& =2
\end{aligned}
$$

Interval Length $=\underline{\text { Interval }}$

$$
\begin{aligned}
& \text { Groups } \\
= & \frac{2}{3} \\
= & 0.67
\end{aligned}
$$

The object of research in this study is the people who occupy the units in Rusunawa Jatinegara, East Jakarta. The number of people who occupy 518 units in Rusunawa Jatinegara as many as 2,180 people with the total of $\mathrm{KK}$ is 631 KK. The number of units in tower A is 266 units, and the number of units in tower B is 252 units. In this study, the sample of population size is done by using the number of units in Rusunawa because in one unit there are one or two KK, and the function of this research is to know the condition of the environmental health in the unit of Rusunawa Jatinegara compared with the environmental health condition in Kampung Pulo.

To determine the number of the samples, Slovin method is used with the following formula [12]:

Note:

$$
n=\frac{N}{N(e)^{2}+1}
$$

$\mathrm{n}=$ Sample Size

$\mathrm{N}=$ Population Size

$\mathrm{e}=$ Desired Critical Value (desired threshold)

It can be calculated from the above formula with the population size 518 units desired threshold as much as $10 \%$ are as follows:

$$
\begin{aligned}
& n=\frac{518}{518(0,1)^{2}+1} \\
& n=83,82=83 \text { unit }
\end{aligned}
$$

From the calculation, the minimum sample size is as much as 83 units in Rusunawa Jatinegara or equal to 83 people who occupy the units in Rusunawa Jatinegara. To present the sampling in Tower A and tower B, the calculation is as follows:

$$
\text { Tower } A=\frac{266}{518} \times 100 \quad \text { Tower } B=\frac{252}{518} \times 100
$$

Tower $A=51,35 \%$

Tower $A=51,35 \% \times 83$

Tower $B=48,65 \% \times 83$

Tower $A=42,62=43$
The sampling technique used in this study is the probability sampling technique, the theory is used for sampling if every element contained in the population has the equal opportunity to serve as a sample, regardless of the items in the component. The types of sampling used by the writer are random sampling; it is the sampling method of all members of the population carried out randomly without the regard of the population class [13].

In this research, descriptive analysis used to determine the socio-economic factors of the respondents which shows the education and income levels of the respondents, and also conducted the correlation and regression analysis to understand the influence of the education level and the income to a public perception about the environmental health in Rusunawa Jatinegara compared with the environmental health in Kampung Pulo. Those data were analyzed using SPSS 16.0. Socio-economic condition is an important factor that can affect the resilience or behavior of people in facing disaster [14].

The correlation analysis used is Spearman correlation because the data scale for both correlated variables come from the different level which is the ordinal data scale and the numerical data scale. The guidelines to provide the interpretation of the correlation coefficient or $r$ value is as follows:

$0-0.199 \quad$ Very low correlation between $\mathrm{x}$ and $\mathrm{y}$ variable

$0.2-0.399$ Low correlation between $\mathrm{x}$ and $\mathrm{y}$ variable

$0.4-0.599$ Moderate correlation between $\mathrm{x}$ and $\mathrm{y}$ variable

$0.6-0.799$ Strong correlation between $\mathrm{x}$ and $\mathrm{y}$ variable

$0.8-1.00 \quad$ Very strong correlation between $\mathrm{x}$ and $\mathrm{y}$ variable

In this research, the sample used is 84 respondents, factor (x) or independent that will be calculated in this research is the level of education and income, and factor (y) or 
dependent is the public perception to the difference of the environmental health in Rusunawa Jatinegara and the environmental health in Kampung Pulo [15]. The correlation coefficient to be calculated is as follows:

a. $\mathrm{x}_{1} \rightarrow \mathrm{y}$, the relationship between the educational level with the public perception about the environmental health at Rusunawa compared in Kampung Pulo.

b. $\mathrm{x}_{2} \rightarrow \mathrm{y}$ is the relation between the income and the public relation about the environmental health in Rusunawa Jatinegara compared within Kampung Pulo.

c. $\mathrm{x}_{1}+\mathrm{x}_{2} \rightarrow \mathrm{y}$ is the relationship between the educational and the income levels with the environmental health in Rusunawa Jatinegara compared within Kampung Pulo.

To predict how strong the relationship between the variables $\mathrm{x} 1$ (level of education) and $\mathrm{x} 2$ (income) with variable $\mathrm{y}$ (community perception), the researcher uses multiple linear regression formula with the following formula:

$$
y=a+\beta_{1} x_{1}+\beta_{2 x_{2}}+\varepsilon
$$

\section{Result and Discussion}

The average age of the respondents is 41 years with the youngest age of the respondents is 21 years, and the oldest one is 66 years old. The average of the family members in Rusunawa Jatinegara is 4 people in one unit, the highest number is 7 people, and the lowest one is one people in one unit. The average of the respondents' expenditure is IDR 2,420,000 with the minimum spending is IDR 800,000 and the maximum expenditure of the respondents are IDR 6,000,000.

The majority of the respondents' education level is in the level of Junior high and Senior high schools which means the level of their education is accordance to the minimum standards of DKI Jakarta's residents. The respondents with graduated from Junior and Senior High School were 71\%, the respondents with primary education level were $24 \%$, and the respondents with the academic education level was 5\%. The lowest education of the respondents is in the elementary education level, and the highest education of the respondents is academic (D3).

According to Indonesia Statistical Bureau (BPS) standard, the majority of the residents' income of Rusunawa Jatinegara is included in a high income which ranged between Rp. 2,500,000-3,500,000. The number of the respondents who have a high income is $49 \%$, the respondents who earn very high income is $8 \%$, and the respondents who have low income is $18 \%$. Note that very high income is above IDR 3.5 million/month, high income is IDR $2.5-3.499$ million/month, moderate income is IDR 1.5 - 2.499 million/month and low income is below IDR 1.5 million/month.

The validity test serves to determine the extent to which a measuring instrument can be used. Validity is the aspect of the accuracy of measurement; a valid measuring instrument can perform its measuring function correctly, and also has high efficiency. The sense of precision here is that it can detect the different small size of the attributes measured. The valid instrument means that the measuring tool used to get the data is valid or can be used to measure what should be measured. The validity test used in this research is Pearson Product Moment correlation which will be calculated using SPSS 16.0. A valid question is if $r_{\text {count }} \geq r_{\text {table with } 90 \%}$ significance level, but if $r_{\text {count }} \leq r_{\text {table }}$ with $90 \%$ significance level then the instrument is declared invalid. Table 1 shows, from 24 questions about the health of the house, there are 4 items of invalid queries or those are $r_{c o u n t} \leq$ rtable. Therefore, the 4 categories are not feasible as an instrument for measuring the research, while for the other 20 questions is valid because $r_{\text {count }}$ $\geq \mathrm{r}_{\text {table, }}$ therefore, 20 items of the issues were used in this research.

Table 1. Validity Test

\begin{tabular}{|c|c|c|c|c|}
\hline No & Category & rhitung & $\mathbf{r}_{\text {tabel }}$ & Validity \\
\hline 1 & Flood & 1 & 0.1786 & Valid \\
\hline 2 & Noise & 0.269 & 0.1786 & Valid \\
\hline 3 & Dust & 0.476 & 0.1786 & Valid \\
\hline 4 & Temperature & 0.387 & 0.1786 & Valid \\
\hline 5 & Garden & 0.440 & 0.1786 & Valid \\
\hline 6 & Water Pipe & 0.622 & 0.1786 & Valid \\
\hline 7 & Water Supply & 0.582 & 0.1786 & Valid \\
\hline 8 & $\begin{array}{c}\text { Water Quality } \\
\text { Wastewater }\end{array}$ & 0.592 & 0.1786 & Valid \\
\hline 9 & $\begin{array}{l}\text { Treatment } \\
\text { Septic Tank }\end{array}$ & 0.664 & 0.1786 & Valid \\
\hline 10 & Condition & 0.295 & 0.1786 & Valid \\
\hline 11 & Waste Management & 0.478 & 0.1786 & Valid \\
\hline 12 & Existence of Flies & 0.498 & 0.1786 & Valid \\
\hline 13 & Existence of Rats & 0.290 & 0.1786 & Valid \\
\hline 14 & Greenery & 0.461 & 0.1786 & Valid \\
\hline 15 & Building Materials & 0.018 & 0.1786 & Not Valid \\
\hline 16 & Floor Condition & 0.011 & 0.1786 & Not Valid \\
\hline 17 & Room Ventilation & 0.213 & 0.1786 & Valid \\
\hline 18 & Rooms Layout & 0.644 & 0.1786 & Valid \\
\hline 19 & Kitchen Ventilation & 0.100 & 0.1786 & Not Valid \\
\hline 20 & Kitchen Condition & 0.026 & 0.1786 & Not Valid \\
\hline 21 & Lighting & 0.604 & 0.1786 & Valid \\
\hline 22 & Overall Ventilation & 0.252 & 0.1786 & Valid \\
\hline 23 & Bedroom Size & 0.433 & 0.1786 & Valid \\
\hline 24 & Building Size & 0.427 & 0.1786 & Valid \\
\hline
\end{tabular}

Source: Author

The invalid questions include the building materials, floor conditions, kitchen ventilation, and kitchen or food storage conditions. An invalid item means that the itemn is inaccurate in performing its measuring function.

Reliability is a measure of stability and consistency of the respondents in answering the questions which exist on the questionnaire if the question is repeatedly done. In this research, reliability test used the formula of coefficient Alpha or Alpha Cronbach, reliability calculations further using the computer device SPSS 16.0. The question item which will be tested reliability is only a question item that has been declared in the previous validity test.

Table 2. Reliability Test

\begin{tabular}{ccc}
\hline$r_{\text {count }}$ & rable & N of Items \\
\hline \hline 0,648 & 0.1786 & 20 \\
\hline
\end{tabular}

From the table of reliability test with 20 questions, can be declared reliable because $r_{\text {count }} \geq r_{\text {table, }}, r_{\text {count }}$ generated from the reliability test is 0.648 , while $\mathrm{r}_{\text {table }}$ contained in $\mathrm{r}$ table is 0.1786 , so the question can be said reliable because the value $r_{\text {count }} \geq r_{\text {table }}$ or $0,648 \geq 0.1786$.

According to the residence perception, $60 \%$ of 20 questions or indicators of the environmental health in 
Rusunawa are better than in Kampung Pulo, and $15 \%$ out of 20 questions are the same, and $25 \%$ of 20 questions are worse (figure 1).

There are some indicators with better perception according to the perception of society in Kampung Pulo when compared with in Rusunawa jatinegara, such parameters are water quality, lighting, rooms layout, sleeping area and building area. While room ventilation, sewerage, and air temperature have same perception. There are 12 indicators of the environmental health in Rusunawa Jatinegara which are better than those in Kampung Pulo; those indicators are the overall ventilation, greenery, the existence of rats, flies, wastewater treatment, septic tank conditions, waste management, water supply, garden, dust, noise, and flood.

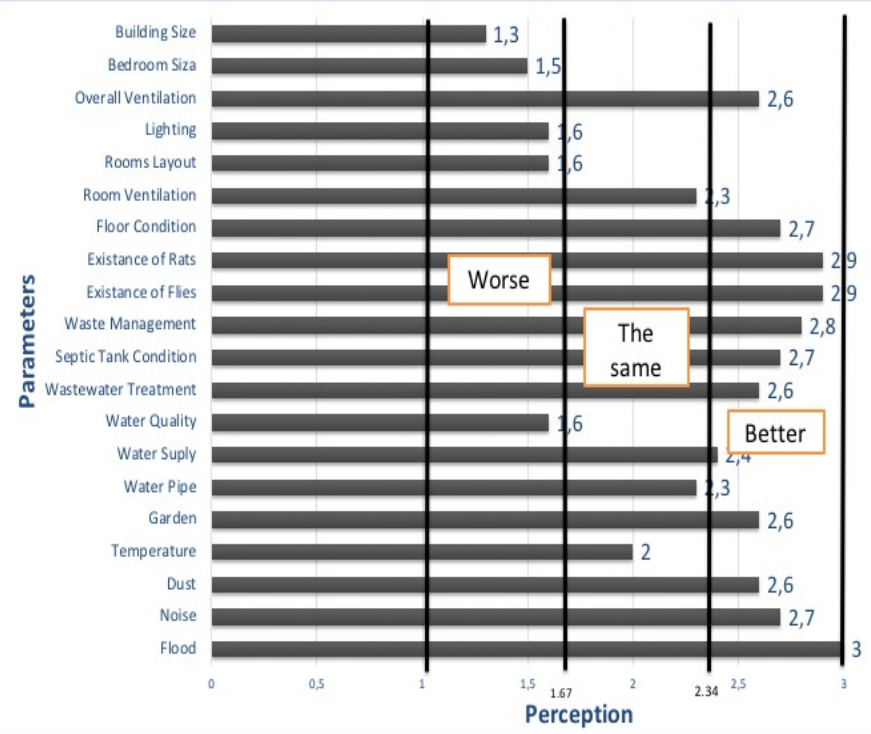

\section{Figure 1. Residences' Perception of Environmental Health of Rusunawa}

According to the public perception, water quality in Rusunawa Jatinegara is worse than the water quality in Kampung Pulo, because the clean water in Rusunawa often cause itching on the skin and can not be used as drinking water. The source of water in Rusunawa Jatinegara comes from PT Aetra, while the source of clean water in Kampung Pulo comes from the groundwater. The quality of fresh water that meets the standard or clean water contaminated biologically or chemically can cause the negative impact on the public health. Therefore, the clean water which will be distributed to the quality community must already meet the standards.

Natural lighting from sunlight in Rusunawa is worse than in Kampung Pulo because every unit in Rusunawa is not exposed to the direct sun exposure. The natural light makes the occupancy healthier because it can kill the germs and bacteria that cause some diseases such as ISPA, tuberculosis, influenza, eye disease and others. Therefore, the lighting is essential factor for healthy house, to overcome the problem of lighting artificial lighting such as lamps can be used.

The arrangement of the room (rooms layout) in Rusunawa as seen in figure 2 that the location of the kitchen and living room is in the same place is not convenience according to respondents. The arrangement of the previous house in Kampung Pulo is better because it is laid out by its function such as for the TV room, living room, kitchen, bed room, and others.

The other parameters that according to the perception of the community is worse are the width of the bedroom and the overall building area of the house. According to the occupants the size of bedroom and the house is not as big as of the bedroom in their previous house. Almost every house in
Kampung Pulo consist of two or more floors while in Rusunawa only one floor and the size are narrow. According to [16], the situation of live density can increase the pollution factor in the house. However, the problem is being handled by the management of Rusunawa by listing the number of family members who live in one unit. If in one unit there are more than 7 people it will be given the additional units.

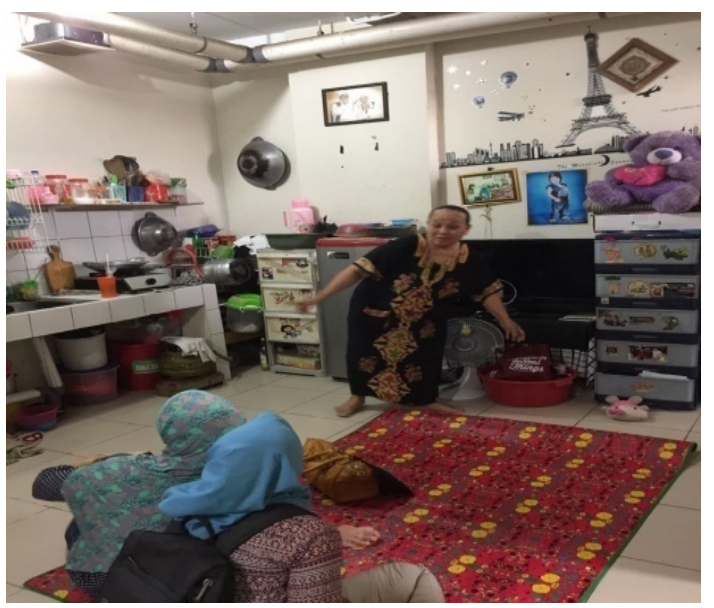

Figure 2. Kitchen and living area

The better indicators according to the community perceptions are $60 \%$ from 20 questions. Some of the better environmental health indicators in Rusunawa Jatinegara according to the public opinion are the condition of flood, and the existence of animal that can transmit disease such as rats and flies.

The overall of the 20 factors contained in Health Ministerial Decree 829/Menkes/SK/VII/1999 on the environmental health in residential homes on home and sanitation groups according to the community perception explained that in terms of the environmental health, the community feels that the environmental health in Rusunawa is better if compared with the environmental health in Kampung Pulo. It is evidenced by $60 \%$ from 20 environmental health indicators which are 11 variables of it according to the public perception is better than in Kampung Pulo.

The public perception of the environmental health in Rusunawa Jatinegara compared with the environmental health in Kampumg Pulo is better, (stated by 42 of 84 respondents), while 38 respondents said the same and 4 respondents say worse.

The analysis of the education level and the income influence to the perception was used to know how significant the impact of the education level and the income to the public opinion about the environmental health in Rusunawa Jatinegara when compared with the environmental health in Kampung Pulo. The analysis used in this study is the correlation and regression, the relationship used to know the correlation between the education and the perception, and the regression analysis is used to know the magnitude of the influence of education and income level to the public opinion about the environmental health in Rusunawa Jatinegara compared with the environmental health in Kampung Pulo.

The results of correlation analysis between the education levels with the public perception, value (r) is 0,242 ; this shows the low relation between the education levels with the public opinion. While the direction is positive that indicates the higher the education, the higher the public perception of the environmental health differences in Rusunawa with the environmental health in Kampung Pulo. The influence of the education level on the public opinion about the environmental health in Rusunawa is $24,2 \%$. The influence of the income level to the public perception with value (r) equal to 0,170 , 
indicates the relation existence of the income level to the public opinion is very low, the positive correlation value shows the higher the income level hence, the higher the perception society about the environmental health in Rusunawa when compared it with the environmental health in Kampung Pulo. The effect of the income level on the public perception is $17 \%$.

The results of multiple linear regression tests which is used to get the regression equation between the education level and the income to the public perceptionalso to understand the influence of each variable partially are as follows:

$$
\text { Public perception }=39.218+2.270\left(\mathrm{X}_{1}\right)+0.642\left(\mathrm{X}_{2}\right)+2.160
$$

From the equation, we can conclude that:

a. The constant value 39.218 means that if the level of the education and the income is 0 , then the amount of the public perception is 39.218 .

b. If there is a one-time increase in the public perception of the education, then there is an increase in the public opinion of 2.270 which means that there is a definite relationship between the levels of education with the public perception.

c. If there is a one-off increase in income levels, then there is an increase in the public perception of 0.624 which means that there is a definite relationship between the levels of education with the public perception.

In addition to obtaining regression equations, in the table, can produce t-test to determine the effect of the education and the income levels on public perception of the environmental health partially. The following explanation of the test of each variable partially:

a. The influence of the education level on the public perception

The test results obtained $t_{\text {count }}$ value for the education variables greater than $t_{\text {table, }}$ with $t_{\text {count }} 2,031$ and $t_{\text {table }}$ for $\mathrm{df}$ 82 shows the number 1,66365 and a significant value smaller than $10 \%$ hence there is significant influence of the education level to the public perception.

b. The influence of the income levels on the public perception

The rest results obtained $t_{\text {count }}$ value for the income variable is smaller than $t_{\text {table, }}$ with $t_{\text {count }}$ of 1,011 and $t_{\text {table }}$ for df 82 shows the number 1.66365 and the significant value higher than $10 \%$ hence there is no influence of the income level to the public perception.

Table 2. shows the Model Summary, $8.4 \%$ of the public perception of the comparison between the environmental health in Rusunawa Jatinegara and in Kampung Pulo influenced by the level of the education and income. While $91.4 \%$ of the people's perception is influenced by the other variables that not be surveyed.

Table 2. Model Summary

\begin{tabular}{ccccc}
\hline \multicolumn{5}{c}{ Model Summary } \\
\hline Model & $R$ & R Square & $\begin{array}{c}\text { Adjusted R } \\
\text { Square }\end{array}$ & $\begin{array}{c}\text { Std. Error of } \\
\text { the Estimate }\end{array}$ \\
\hline \hline & $.290^{\mathrm{a}}$ & 0.084 & 0.061 & 4.809 \\
\hline \hline
\end{tabular}

The noise level in Rusunawa Jatinegara exceeds 55 $\mathrm{dB}$, it is because of the location of Rusunawa is close to the highway. The noise levels in Rusunawa requires serious handling because $2 / 3$ of the human life is in the home and the noise in the housing can affect both psychological and physical comfort. However, the noise level in Rusunawa Jatinegara is better than the noise in Kampung Pulo.
The process of wastewater management in Rusunawa Jatinegara is not comply with the regulations, because the equipment used for the operation of the wastewater management in Rusunawa does not run well, the wastewater is being filtered against the sludge, the filtered slurry will then be given to the $3^{\text {rd }}$ party namely PT. PAL Jaya, while the waste water generated directly channeled to the city channel. Other parameters which are not comply with Regulation of Health Ministry No 829 of 1999 is the arrangement of the room (rooms layout). The rooms layout in Rusunawa Jatinegara is not in accordance with the rules, because the location of the kitchen and living room is in one room, whereas according to regulation that the space in the house should be arranged by the function as a living room, dining room, bedroom, kitchen, bathroom, and the children's playroom. Similarly, as the result of the interview, according to the perception of the residents, the rooms layout in Rusunawa is worse when compared with the previous house.

\section{Summary}

as follows:

The conclusion can be obtained from this research are

1. The majority of the education level of Rusunawa Jatinegara residents is secondary education (Junior or High School which is the minimjum standard of DKI Jakarta).

2. The majority of the income levels of Rusunwa Jatinegara residents are high income of IDR 2,500,000 - IDR $3,500,000$.

3. There are 5 of 20 parameters of the environmental health in Rusunawa Jatinegara which according to the public perception is worse when compared to Kampung Pulo; those parameters are water quality, rooms layout, sunlight, sleeping area and building area.

4. The parameter according to the public perception which is far better in Rusunawa compared within Kampung Pulo that is flood and animal transmitting diseases such as rats and flies.

5. Partially the level of education affects the public perception while the income level does not change the public perception of the comparison between the environmental health in Rusunawa Jatinegara and the environmental health in Kampung Pulo.

6. Simultaneously the level of the education and income has positive impact to the public perception on the comparison of the environmental health in Rusunawa Jatinegara and the environmental health in kampong Pulo.

7. The resulting regression equation is as follows: Public perception $=39.218+2.270\left(\mathrm{X}_{1}\right)+0.642\left(\mathrm{X}_{2}\right)+$

$$
2.160
$$

Which means if there is a one-time increase in education level there is an increase in the public perception of 2.270 and if there is one increase in income levels than there is an increase in public perception of 0.642 .

8. According to the observation of 20 parameters of environmental health at Rusunawa Jatinegara, three are not comply to the Minister of Health Regulation No. 829/Menkes/SK/VII/1999, those are the level of noise, wastewater treatment, and the layout of the room.

\section{Suggestion}

The recommendation from this research are as follows:

1. Checking the quality of supply water and cleaning the water tank periodically. 
2. The improvement to the artificial lighting using renewable solar energy.

3. Checked the quality of wastewater that will be channeled to the city channel.

4. The improvement of the domestic wastewater treatment process.

5. For further research, an analysis of the effect of the comfort level on a comparison of the public perception on the environmental health in Rusunawa Jatinegara with the environmental health in Kampung Pulo and weighted each parameter to be in analyzed.

\section{References}

[1] D. A. P. Sari and S. Kawashima, "Poverty Mapping And Poverty Analysis In Indonesia," J. Agro Ekon., vol. 28, no. 1, p. 95, Aug. 2016.

[2] BPS, Statistik Daerah Provinsi DKI Jakarta 2015. 2015.

[3] S. Dutta, \& M. R.-I. J. of E., and U. 2018, "Rural Urban Classification (RUC) and its impact on funding pattern for urban development in the context of Indian cities," Sciencepubco.Com, vol. 7, pp. 20-26, 2018.

[4] N. K. Singh, A. Kumar, R. Singh, and Anita, "Design and development of air quality management devices with sensors and web of things," Int. J. Eng. Technol., vol. 7, no. 2, pp. 107-111, 2018.

[5] D. A. P. Sari, S. Innaqa, and Safrilah, "Hazard, Vulnerability and Capacity Mapping for Landslides Risk Analysis using Geographic Information System (GIS)," in IOP Conference Series: Materials Science and Engineering, 2017.

[6] D. A. P. Sari, A. Sugiana, R. Y. Ramadhonah, S. Innaqa, and R. Rahim, "Kampung Pulo Environmental Planning Observed From Biophysical Aspects As Adaptation of Flood in Jakarta," Int. J. Eng. Technol., vol. 7, no. 2.3, pp. 82-87, 2018.

[7] D. A. Puspito Sari, I. Listiyowati, T. Nefianto, and Lasmono, "The Discrepancy between The Programs and Disaster Management Policy in Klapanunggal District, Bogor, West Java," IOP Conf. Ser. Earth Environ. Sci., vol. 135, p. 012011, Mar. 2018.

[8] A. Mursidi and D. A. P. Sari, "Management of Disaster Drought in Indonesia," J. Terap. Manaj. DAN BISNIS, vol. 3, no. 2, p. 165 , Oct. 2017.

[9] N. Mamnunia, D. A. P. Sari, and H. Heridadi, "The Influence of Leadership and Competence in Puskesmas Preparedness for Supporting Flood Disaster Management (Case Study of Samarinda City in East Kalimantan Province, Indonesia)," ADRI Int. J. Environ. Disaster Manag., vol. 1, no. 1, pp. 18-26, Jun. 2017.

[10] Republik Indonesia, "Peraturan Menteri Negara Perumahan Rakyat tentang Pengelolaan Rumah Susun No. 14 tahun 2007," pp. 1-50, 2007.

[11] Menteri Kesehatan Republik Indonesia, "Persyaratan Kesehatan Perumahan Keputusan Menteri Kesehatan RI Nomor. 829/Menkes/SK/VII/1999," Persyaratan Kesehatan Perumahan. 1999.

[12] D. A. P. Sari, M. Malahayati, T. Nefianto, and I. Kertawidana, "Disaster Early Warning and Information Services Meteorology, Climatology and Geophysics Agency's Employees Performance Observed from their Motivation and Competency," Int. J. Multi Discip. Sci., vol. 1, no. 2, pp. 129-136, 2018.

[13] Sugiyono, Metode Penelitian Administrasi. 2002.

[14] D. A. P. Sari, F. Rumambi, and Ratih Nurmasari, "Social Economic Resilience in Facing Land and
Forest Fire Disaster," vol. 4, no. 1, pp. 10-16, 2018.

[15] I. Ghozali, Aplikasi Analisis Multivariate Dengan Program SPSS, Fourth. Badan Penerbit Universitas Diponegoro, 2006.

[16] Getrudis, "Hubungan antara Kadar Partikulat Udara Rumah Tinggal dengan Kejadian ISPA pada Balita di Sekitar Pabrik Sement Indocement.," Universitas Indonesia, 2010. 